\title{
International recognition for ageing research: John Scott Award-2014 to Leonard Hayflick and Paul Moorhead
}

\author{
Suresh Rattan
}

Received: 21 July 2014/ Accepted: 23 July 2014/Published online: 12 August 2014

(C) Springer Science+Business Media Dordrecht 2014

It is with great pleasure and pride that we share the news of the award of the 2014 "City of Philadelphia John Scott Award", to Dr. Leonard Hayflick and Dr. Paul Moorhead, for their research on ageing.

The press release announcing the award states that: "from the first awarded in 1822, the Award is the oldest scientific award in the United States and, as a legacy to Benjamin Franklin, they are in the historic company of past winners who include Marie Curie, Thomas Edison, Jonas Salk, Irving Langmuir, Nicola Tesla, Guglielmo Marconi, R. Buckminister Fuller, Sir Alexander Fleming, Sir Howard Florey, Edwin Land, and the Wright Brothers... The award includes a cash prize, a medal and a certificate and is given to the "most deserving" men and women whose inventions have contributed in some outstanding way to the "comfort, welfare and happiness" of mankind... The ceremony and reception will take place on Friday, November 21, 2014 in Benjamin Franklin Hall at the American Philosophical Society, Philadelphia, PA."

The award announcement also mentions that: “Dr. Hayflicks' research discoveries, mostly made at the Wistar Institute, occurred in the fields of aging, cancer and microbiology.... He is a member of twenty scientific societies in which he has held several high offices including President of the Gerontological Society of America, founding member of the Council of the National Institute on Aging, NIH and chairman of its Executive Committee.... He is an Academician of the Ukrainian Academy of Medical Sciences, corresponding member of the Société de Biologie of France, recipient of the Van Weezel Award by the European Society for Animal Cell Technology and the Lord Cohen of Birkenhead Medal by the British Society for Research on Aging.... In the early 1960s Hayflick discovered that cultured normal human cells have a limited capacity to replicate (commonly referred to as the "The Hayflick Limit.") and overturned a dogma in which it was believed, since the field began in 1907, that all cultured cells are potentially immortal...”.

Biogerontology thanks and salutes these pioneers for their life long work in bringing the scientific rigour, credibility and prestige to the study of ageing.

S. Rattan $(\square)$

Aarhus University, Aarhus, Denmark

e-mail: rattan@mb.au.dk 